\title{
Fully water-blown polyisocyanurate-polyurethane foams with improved mechanical properties prepared from aqueous solution of gelling/ blowing and trimerization catalysts
}

https://doi.org/10.1515/epoly-2019-0028

Received October 21, 2018; accepted December 17, 2018.

\begin{abstract}
Fully water-blown polyisocyanurate-polyurethane (PIR-PUR) foams with improved mechanical properties have been prepared using aqueous solutions of metalammonia complex, $\mathrm{Cu}(\mathrm{Am})$ or $\mathrm{Zn}(\mathrm{Am})$, as gelling/blowing catalysts and potassium octoate (KOct) solution in diethylene glycol as a trimerization catalyst. Two catalyst mixtures, $\mathrm{Cu}(\mathrm{Am})+\mathrm{KOct}$ and $\mathrm{Zn}(\mathrm{Am})+\mathrm{KOct}$, were obtained as homogeneous aqueous solutions. In comparison to commercial catalyst system, DMCHA + KOct $(\mathrm{DMCHA}=\mathrm{N}, \mathrm{N}-$ dimethylcyclohexylamine), $\mathrm{Cu}(\mathrm{Am})$ and $\mathrm{Zn}(\mathrm{Am})$ could be miscible with KOct solution and water easier than DMCHA. This miscibility improvement led $\mathrm{Cu}(\mathrm{Am})+\mathrm{KOct}$ and $\mathrm{Zn}(\mathrm{Am})+\mathrm{KOct}$ to show faster catalytic reactivity in PIR-PUR foam reactions than DMCHA+KOct. All obtained PIR-PUR foams showed self-extinguishing properties and achieved HF1 materials. However, PIR-PUR foams prepared from $\mathrm{Cu}(\mathrm{Am})+\mathrm{KOct}$ and $\mathrm{Zn}(\mathrm{Am})+\mathrm{KOct}$ at $\mathrm{NCO}: \mathrm{OH}$ ratio of 2:1 had suitable density for industrial applications and showed higher compressive strength than that prepared from DMCHA+KOct. These foams have high potential to apply as insulations for constructions, core laminates in wall panel or storage tanks.
\end{abstract}

Keywords: fully water-blown polyisocyanurate-polyurethane (PIR-PUR) foams; aqueous catalyst solutions;

\footnotetext{
* Corresponding author: Nuanphun Chantarasiri, Supramolecular Chemistry Research Unit, Department of Chemistry, Faculty of Science, Chulalongkorn University, Bangkok, 10330, Thailand, e-mail: nuanphun.c@chula.ac.th.

Benjatham Sukkaneewat, Program of Petrochemistry and Polymer Science, Faculty of Science, Chulalongkorn University, Bangkok, 10330, Thailand.

Duangruthai Sridaeng, Department of Chemistry, Faculty of Science, Rangsit University, Pathumthani, 12000, Thailand.
}

mechanical properties; self-extinguishing properties; HF1 materials

\section{Introduction}

Polyisocyanurate (PIR) foams are recognized as the efficient thermo-insulations utilized for constructions. Manufacturing processes of PIR foams are similar to those of rigid polyurethane (RPUR) foams. Isocyanurate linkages are formed by cyclotrimerization of excess isocyanate compounds using suitable trimerization catalysts. The outstanding properties of PIR foams over conventional RPUR foams are inherent thermal stability and low flammability (1-4). Meanwhile, unmodified PIR foams with too many isocyanurate crosslinks are extremely fragile and unable to use in practical applications $(2,5)$. Several attempts have been made to reduce the brittleness of PIR foams by substituting some isocyanurate linkages with other linkages, such as oxazolidone, urethane and carbodiimide linkages (6-8). In the case of polyisocyanurate modified with polyurethane (PIR-PUR) foams, attention has been paid to improve their properties. The modification methodology for PIR-PUR foams includes a choice of polyols (9-12), catalysts (13) and blowing agents (14). Typical blowing agents for PIR-PUR foams are hydrochlorofluorocarbons (HCFCs), pentane or their mixtures with water. Meanwhile, the use of only water for fully water-blown PIR-PUR foams have the advantages due to no ozone depleting potential and lower costs than HCFCs $(2,14)$. The good dimensional stability of fully water-blown PIR-PUR foams can be reached with foam density $\geq 43.2 \mathrm{~kg} / \mathrm{m}^{3}(2)$.

In the production of PIR-PUR foams, catalysts serve as important components in determining the final foam properties. Catalyst mixtures between trimerization and gelling/blowing catalysts are required to balance 
the reaction rate of isocyanurate formation, urethane formation and $\mathrm{CO}_{2}$ generation. This results in PIR-PUR foams with desirable properties (15). Typical trimerization catalysts used for isocyanurate formation are carboxylic acid salts, namely potassium octoate (KOct) and potassium acetate (KOAc), and quaternary ammonium salts. Tertiary amines, which are commercial catalysts of RPUR foam, have been used as co-catalysts with trimerization catalysts for PIR-PUR foam preparation. For examples, Gao et al. (16) used the catalyst mixture between the KOct solution in diethylene glycol and $\mathrm{N}, \mathrm{N}$ dimethylcyclohexylamine (DMCHA) in the preparation of PIR-PUR foam nanocomposites. Lövenich et al. (17) investigated starting material effects on trimer formation of PIR-PUR foams, whose reactions were accelerated by KOAc and DMCHA. Modesti et al. (18) prepared PIR-PUR foams with different charring agents using KOct and pentamethyldiethylenetriamine as catalysts.

DMCHA is a good gelling/blowing catalyst. However, for fully water-blown PIR-PUR foams, the drawback of using DMCHA is its non-homogeneous mixture with KOct in diethylene glycol. Therefore, we proposed to use gelling/blowing catalysts as aqueous solutions, which should be easily miscible with KOct in diethylene glycol. In this case, the aqueous solutions of copper- and zincammonia complex [Cu(Am) and $\mathrm{Zn}(\mathrm{Am})$, respectively] are good candidates as the gelling/blowing catalysts.

Addition of an ammonia solution to copper(II) and zinc(II)aqueoussolutionsresultsinsuccessivereplacement of coordinated water in $\mathrm{Cu}\left(\mathrm{H}_{2} \mathrm{O}\right)_{6}{ }^{2+}$ and $\mathrm{Zn}\left(\mathrm{H}_{2} \mathrm{O}\right)_{6}{ }_{6}^{2+}$ by $\mathrm{NH}_{3}$ to give copper-ammonia complex $\left[\mathrm{Cu}\left(\mathrm{NH}_{3}\right)_{\mathrm{n}}\left(\mathrm{H}_{2} \mathrm{O}\right)_{6-\mathrm{n}}\right]^{2+}$ (19) and zinc-ammonia complex $\left[\mathrm{Zn}\left(\mathrm{NH}_{3}\right)_{\mathrm{n}}\left(\mathrm{H}_{2} \mathrm{O}\right)_{6-\mathrm{n}}\right]^{2+}$ (20), respectively (Scheme 1). The applications of metalammonia complexes have been reported as follows: in the preparation of rayon fibers, which are the regenerated cellulose fibers and have their similar texture to natural silk, cellulose fibers were dissolved in $\left[\mathrm{Cu}\left(\mathrm{NH}_{3}\right)_{4}\left(\mathrm{H}_{2} \mathrm{O}\right)_{2}\right]$ $(\mathrm{OH})_{2}$ solution or Schweizer's reagent, ripened, extruded from a spinneret and precipitated in order to obtain the silk-like textile fibers (21). In hydrometallurgical process, ammonia leaching has received great interest since metals, such as copper and zinc, can be recovered through the formation of metal-ammonia complexes. Extraction of copper(II) and zinc(II) in an ammonia solution leads to the investigation of copper- and zinc-ammonia complex structures in an ammonia solution (22-25). The chemistry of metal-ammonia complexes was applied to prepare hollow copper- and zinc-oxides/nitrogen doped graphene hybrids using metal-ammonia complexes as precursors (26). The $\left[\mathrm{Cu}\left(\mathrm{NH}_{3}\right)_{\mathrm{x}}\right]^{2+}$ form of heulandite (CuammHEU) was prepared by the treatment of the Na-form of natural heulandite crystals with the copper-ammonia complex solution. The structure of the complex contained in the A channel of CuammHEU was disordered square planar $\left[\mathrm{Cu}\left(\mathrm{NH}_{3}\right)_{4}\right]^{2+}$ having two axial $\mathrm{H}_{2} \mathrm{O}$ ligands to give the elongated octahedron structure (27). Copper-substituted ZSM-5 catalysts were obtained from the ion exchange process of $\mathrm{H}-\mathrm{ZSM}-5$ in the solution of copper-ammonia complex, $\left[\mathrm{Cu}\left(\mathrm{NH}_{3}\right)_{\mathrm{n}}\left(\mathrm{H}_{2} \mathrm{O}\right)_{6-\mathrm{n}}\right]^{2+}$. The composition of the complexes in the solution related to copper:ammonia ratio and $\mathrm{pH}$ of the solution. The $\left[\mathrm{Cu}\left(\mathrm{NH}_{3}\right)_{4}\left(\mathrm{H}_{2} \mathrm{O}\right)_{2}\right]^{2+}$ complex was predominant at $\mathrm{pH}$ 8.5-10.5 and appeared as the most stable form (28).

To the best of our knowledge, aqueous solution of metal-ammonia complexes has never been reported as the catalyst in PIR-PUR foam preparation. Therefore, the aims of this study are to synthesize metal-ammonia complexes $[\mathrm{Cu}(\mathrm{Am})$ and $\mathrm{Zn}(\mathrm{Am})]$ in aqueous solution form for using as gelling/blowing catalysts of fully water-blown PIR-PUR foam and to investigate their catalytic activity effects on PIR-PUR foam properties. These catalyst solutions were expected to have improved miscibility with KOct solution in diethylene glycol to obtain the homogeneous catalyst systems composed of $\mathrm{Cu}(\mathrm{Am})+\mathrm{KOct}$ or $\mathrm{Zn}(\mathrm{Am})+\mathrm{KOct}$. Physical, mechanical and flame retardant properties of PIR-PUR foams catalyzed by $\mathrm{Cu}(\mathrm{Am})+\mathrm{KOct}$ and $\mathrm{Zn}(\mathrm{Am})+$ KOct were investigated and compared to that accelerated by DMCHA+KOct.

\section{Experimental}

\subsection{Materials}

Starting materials used for synthesis of $\mathrm{Cu}(\mathrm{Am})$ and $\mathrm{Zn}(\mathrm{Am})$ were copper(II) acetate monohydrate $\left[\mathrm{Cu}\left(\mathrm{CH}_{3} \mathrm{CO}_{2}\right)_{2} \cdot \mathrm{H}_{2} \mathrm{O}\right.$, Sigma-Aldrich, St. Louis, MO, USA],

\section{$\mathrm{M}\left(\mathrm{H}_{2} \mathrm{O}\right)_{6}{ }^{2+}+\mathrm{n} \mathrm{NH}_{3} \rightleftharpoons \mathrm{M}\left(\mathrm{NH}_{3}\right)_{n}\left(\mathrm{H}_{2} \mathrm{O}\right)_{6-\mathrm{n}}{ }^{2+}+\mathrm{n} \mathrm{H}_{2} \mathrm{O}$}

\section{$M=\mathrm{Cu}$ and $\mathrm{Zn}$}

Scheme 1: Formation of metal-ammonia complexes. 
Zinc(II) acetate dihydrate $\left[\mathrm{Zn}\left(\mathrm{CH}_{3} \mathrm{CO}_{2}\right)_{2} \cdot 2 \mathrm{H}_{2} \mathrm{O}\right.$, Nacalai Tesque, Kyoto, Japan] and ammonia $\left(\mathrm{NH}_{3}\right.$ ) solution with $30 \mathrm{wt} \%$ of concentration (Carlo Erba, Val de Reuil, France).

Starting materials used for foam preparation were supplied by IRPC Public Company Ltd. as follows: Polimaxx $^{\circledR} 4221$ polyether polyol, B9001 ${ }^{\circledR}$ PMDI $(\% \mathrm{NCO}=31.0 \mathrm{wt} \%)$, Tegostab ${ }^{\circledR} \mathrm{B} 8460$ surfactant, N,Ndimethylcyclohexylamine (DMCHA), potassium octoate (KOct, Dabco ${ }^{\circledR} \mathrm{K}-15,70 \mathrm{wt} \%$ in diethylene glycol).

\subsection{Experimental design}

The catalytic activity of $\mathrm{Cu}(\mathrm{Am})$ and $\mathrm{Zn}(\mathrm{Am})$ in gelling/ blowing reactions was initially screened in RPUR foam system. Then, fully water-blown PIR-PUR foams were prepared using $\mathrm{Cu}(\mathrm{Am})+\mathrm{KOct}$ and $\mathrm{Zn}(\mathrm{Am})+\mathrm{KOct}$ as catalysts. Their experimental data were compared to those accelerated by DMCHA+KOct (the commercial catalyst system).

\subsection{Synthesis of $\mathrm{Cu}(\mathrm{Am})$ and $\mathrm{Zn}(\mathrm{Am})$}

A $25.0 \mathrm{wt} \%$ aqueous solution of $\mathrm{Cu}(\mathrm{Am})$ was prepared as follows: distilled water $(3.21 \mathrm{ml})$ was added to $30 \mathrm{wt} \%$ ammonia solution $(1.27 \mathrm{ml}, 19.91 \mathrm{mmol})$. The total volume of distilled water is $4.0 \mathrm{ml}$. Then, $\mathrm{Cu}\left(\mathrm{CH}_{3} \mathrm{CO}_{2}\right)_{2} \cdot \mathrm{H}_{2} \mathrm{O}(0.662 \mathrm{~g}$, $3.32 \mathrm{mmol}$ ) was added. All chemicals were stirred for $3 \mathrm{~h}$ in order to obtain the clear-blue $\mathrm{Cu}(\mathrm{Am})$ solution without precipitate (Figure S1).

A $25.0 \mathrm{wt} \%$ aqueous solution of $\mathrm{Zn}(\mathrm{Am})$ was synthesized using the same procedure as $\mathrm{Cu}(\mathrm{Am})$ synthesis by employing reactants as follows: $30 \mathrm{wt} \%$ ammonia solution (1.19 $\mathrm{ml}, 18.66 \mathrm{mmol})$, $\mathrm{Zn}\left(\mathrm{CH}_{3} \mathrm{CO}_{2}\right)_{2} \cdot 2 \mathrm{H}_{2} \mathrm{O}(0.682 \mathrm{~g}, 3.11 \mathrm{mmol})$ and distilled water $(3.26 \mathrm{ml})$. A clear-colorless $\mathrm{Zn}(\mathrm{Am})$ solution was obtained without precipitate (Figure S1).

\subsection{Characterization of $\mathrm{Cu}(\mathrm{Am})$ and $\mathrm{Zn}(\mathrm{Am})$}

The $\mathrm{pH}$ of $\mathrm{Cu}(\mathrm{Am})$ and $\mathrm{Zn}(\mathrm{Am})$ aqueous solutions was measured using an Ohaus starter $2100 \mathrm{pH}$ meter. The complex formation of metal acetate and ammonia was comfirmed by UV-vis and MALDI-TOF mass spectra obtained from a Varian Cary-50 UV-vis spectrophotometer between 200-900 nm and a Bruker Daltonics mass spectrometer, respectively.

\subsection{Preparation of RPUR and PIR-PUR foams}

Reference RPUR foams and series of PIR-PUR foams were prepared with various equivalent ratios of isocyanate to hydroxyl groups (NCO:OH ratios) and catalyst types. All chemical compositions and abbreviation of the foams are summarized in Table 1. For the abbreviation, RPUR/X-1:1 is defined as RPUR foams catalyzed by the catalyst $\mathrm{X}$ [where $\mathrm{X}=\mathrm{Cu}(\mathrm{Am}), \mathrm{Zn}(\mathrm{Am})$ or DMCHA] using $\mathrm{NCO}: \mathrm{OH}$ ratio of 1:1. PIR-PUR/Y-2:1 and PIR-PUR/Y-2.5:1 are defined as PIR-PUR foams catalyzed by the catalyst mixture $Y$ [where $\mathrm{Y}=\mathrm{Cu}(\mathrm{Am})+\mathrm{KOct}, \mathrm{Zn}(\mathrm{Am})+\mathrm{KOct}$ or DMCHA+KOct] using $\mathrm{NCO}: \mathrm{OH}$ ratios of 2:1 and 2.5:1, respectively. All foams were prepared by cup test and molded methods as reported in the literature (29).

\subsection{Characterization of foams}

Reaction times of RPUR and PIR-PUR foams, namely the start time (the beginning time of foam rising), the gelation time (the starting time of polymer network formation), the tack-free time (the completing time of crosslinking reactions) and the expansion time (the terminating time of blowing reaction), were recorded according to ASTM

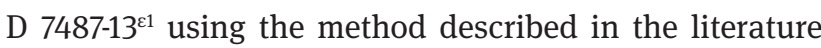
(29). The description of foam appearances used in recording the reaction times is given in Table S1. PIR yield

Table 1: Chemical compositions and abbreviation for RPUR and PIR-PUR foam preparation ( $p b w$ = parts by weight).

\begin{tabular}{|c|c|c|c|}
\hline Composition (pbw) & RPUR foam & \multicolumn{2}{|c|}{ PIR-PUR foam } \\
\hline $\mathrm{NCO}: \mathrm{OH}$ ratio & $1: 1$ & $2: 1$ & $2.5: 1$ \\
\hline PMDI $\left(B 9001^{\circledR}\right)$ & 166.0 & 337.5 & 421.9 \\
\hline Polyether polyol (Polimaxx ${ }^{\circledR}$ 4221) & 100.0 & 100.0 & 100.0 \\
\hline Gelling/blowing catalyst $[\mathrm{Cu}(\mathrm{Am})$ or $\mathrm{Zn}(\mathrm{Am})$ or $\mathrm{DMCHA}]$ & 1.0 & 0.5 & 0.5 \\
\hline Trimerization catalyst (KOct) & - & 3.0 & 3.0 \\
\hline Surfactant (Tegostab ${ }^{\circledR}$ B8460) & 2.5 & 2.5 & 2.5 \\
\hline Blowing agent (water) & 4.0 & 4.0 & 4.0 \\
\hline Abbreviation & RPUR/X-1:1 & PIR-PUR/Y-2:1 & PIR-PUR/Y-2.5:1 \\
\hline
\end{tabular}


and NCO conversion of the foams were studied using the method given in the literature (30). The peak area of corresponding ATR-IR spectra was obtained from a spectrometer (Nicolet-6700, 4000-500 $\mathrm{cm}^{-1}$ range, 16 scans and $4 \mathrm{~cm}^{-1}$ resolution). The density measurement of the cubic foams $\left(30 \times 30 \times 30 \mathrm{~mm}^{3}\right)$ was carried out following ASTM D 1622-08. Compression test was performed through a Hounsfield H $10 \mathrm{KM}$ universal testing machine following ASTM D 1621-16. Compressive strength was collected at $10 \%$ deformation. Morphology of foam cells and char residue of burnt foams were investigated using a JSM-6480LV scanning electron microscope (SEM) with $5 \mathrm{kV}$ acceleration voltage. Thermogravimetric analysis (TGA) data of the foams were obtained from a PerkinElmer Pyris Diamond TG/DTA. The foams were heated from 35 to $800^{\circ} \mathrm{C}\left(10^{\circ} \mathrm{C} / \mathrm{min}\right)$ under $\mathrm{N}_{2}$ atmosphere. Flame retardancy was investigated by UL-94 horizontal burning test following ASTM D 4986-03. Specimen bars $\left(150 \times 50 \times 13 \mathrm{~mm}^{3}\right)$ were marked positions at 25,60 and $125 \mathrm{~mm}$ along foam length and were placed on wire cloth. The free end of specimens was exposed to flame in a horizontal position. Ignition length, burning rate and afterglow time were recorded. \% Limiting oxygen index (LOI) measurement was conducted according to ASTM D 2863-06 using specimen dimension of $125 \times 10 \times 10 \mathrm{~mm}^{3}$.

\section{Results and discussion}

\subsection{Structural determination of $\mathrm{Cu}(\mathrm{Am})$ and $\mathrm{Zn}(\mathrm{Am})$}

The complex formation between metal acetate with ammonia could occur in water to give copper- and zincammonia complexes $[\mathrm{Cu}(\mathrm{Am})$ and $\mathrm{Zn}(\mathrm{Am})]$ in aqueous solution form (Scheme 2). The $\mathrm{Cu}(\mathrm{Am})$ solution without precipitate was obtained at the molar ratio of copper acetate:ammonia $=1: 6$. At this molar ratio, the $\mathrm{pH}$ of
$\mathrm{Cu}(\mathrm{Am})$ solution was 10.63. The synthesis of $\mathrm{Zn}(\mathrm{Am})$ solution used the same molar ratio as $\mathrm{Cu}(\mathrm{Am})$. The $\mathrm{pH}$ of $\mathrm{Zn}(\mathrm{Am})$ solution was 10.38 .

The structural determination of $\mathrm{Cu}(\mathrm{Am})$ and $\mathrm{Zn}(\mathrm{Am})$ in aqueous solution was performed using MALDI-TOF mass spectrometry (Figure 1). The result indicates that the structures of $\mathrm{Cu}(\mathrm{Am})$ and $\mathrm{Zn}(\mathrm{Am})$ are mainly $\left[\mathrm{Cu}\left(\mathrm{NH}_{3}\right)_{4}\left(\mathrm{H}_{2} \mathrm{O}\right)_{2}\right]\left(\mathrm{CH}_{3} \mathrm{CO}_{2}\right)_{2}$ and $\left[\mathrm{Zn}\left(\mathrm{NH}_{3}\right)_{4}\left(\mathrm{H}_{2} \mathrm{O}\right)_{2}\right]\left(\mathrm{CH}_{3} \mathrm{CO}_{2}\right)_{2}$, respectively. Copper and zinc atoms in $\mathrm{Cu}(\mathrm{Am})$ and $\mathrm{Zn}(\mathrm{Am})$, respectively, have six coordinations with four ammonia and two water molecules. Two acetate groups are counter ions. For $\mathrm{Zn}(\mathrm{Am})$, the further ligand exchange of $\mathrm{NH}_{3}$ by $\mathrm{H}_{2} \mathrm{O}$ was observed as the peak of $\left[\mathrm{Zn}\left(\mathrm{NH}_{3}\right)_{2}\left(\mathrm{H}_{2} \mathrm{O}\right)_{4}\right]\left(\mathrm{CH}_{3} \mathrm{CO}_{2}\right)_{2}$. The DFT theoretical study of copper(II)-complex in ammonia-water environment showed the copper-ligand distances as follows: the distances of $\mathrm{Cu}-\mathrm{NH}_{3}$ (ligand 1 to 4) were equal and had the value of $2.06 \AA$, while the distances of $\mathrm{Cu}-\mathrm{H}_{2} \mathrm{O}$ (ligand 5) and $\mathrm{Cu}-\mathrm{H}_{2} \mathrm{O}$ (ligand 6) were 2.58 and $2.60 \AA$, respectively. This suggests that $\left[\mathrm{Cu}\left(\mathrm{NH}_{3}\right)_{4}\left(\mathrm{H}_{2} \mathrm{O}\right)_{2}\right]^{2+}$ can easily lose two $\mathrm{H}_{2} \mathrm{O}$ molecules to give the square planar $\left[\mathrm{Cu}\left(\mathrm{NH}_{3}\right)_{4}\right]^{2+}$, which can catalyze the reaction between $\mathrm{NCO}$ and $\mathrm{OH}$ groups (24). The excess $\mathrm{NH}_{3}$ in metal-ammonia complex aqueous solutions can react with NCO of PMDI.

The $\mathrm{Cu}(\mathrm{Am})$ aqueous solution was also characterized by UV-vis spectroscopy. $\mathrm{Zn}(\mathrm{Am})$ and $\mathrm{Zn}\left(\mathrm{CH}_{3} \mathrm{CO}_{2}\right)_{2}$ are colorless since the d-shell electron configuration of $\mathrm{Zn}^{2+}$ is full $\left(3 \mathrm{~d}^{10}\right)$. Therefore, they did not show the absorption peak in UV-vis spectra. The UV-vis spectra of $\mathrm{Cu}(\mathrm{Am})$ and $\mathrm{Cu}\left(\mathrm{CH}_{3} \mathrm{CO}_{2}\right)_{2}$ were compared (Figure 2). The $\lambda_{\max }$ of $\mathrm{Cu}(\mathrm{Am})$ shifted to $240 \mathrm{~nm}$, while the $\lambda_{\max }$ of $\mathrm{Cu}\left(\mathrm{CH}_{3} \mathrm{CO}_{2}\right)_{2}$ appeared at $245 \mathrm{~nm}$. The spectrum of $\mathrm{Cu}(\mathrm{Am})$ also showed two new shoulder peaks at 287 and $334 \mathrm{~nm}$ and a very small peak at $620 \mathrm{~nm}$ with small $\varepsilon$ value of 49 . This agrees with the data reported in the literature (22). UV-vis spectroscopy was employed to study solutions of copper-ammonia complex prepared using $\mathrm{CuCl}_{2} \cdot 2 \mathrm{H}_{2} \mathrm{O}, \mathrm{NH}_{4} \mathrm{Cl}$ and $\mathrm{NaOH}$ (for $\mathrm{pH}$ control). The solutions were prepared at various $\mathrm{pH}$ under the specific conditions. The complex solutions showed the

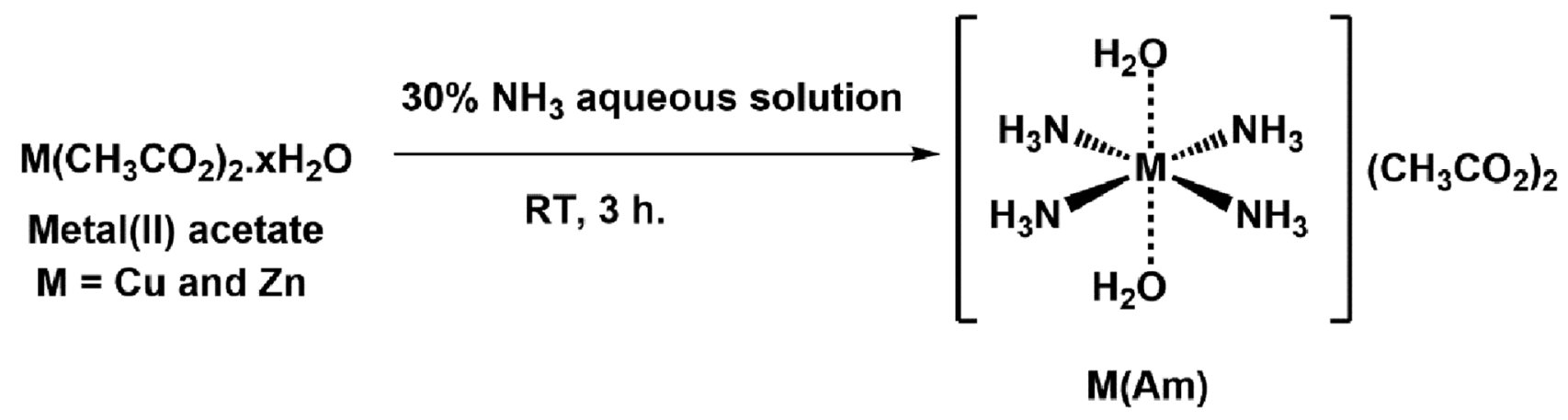

Scheme 2: Synthesis of metal-ammonia complex [M(Am)] aqueous solutions. 

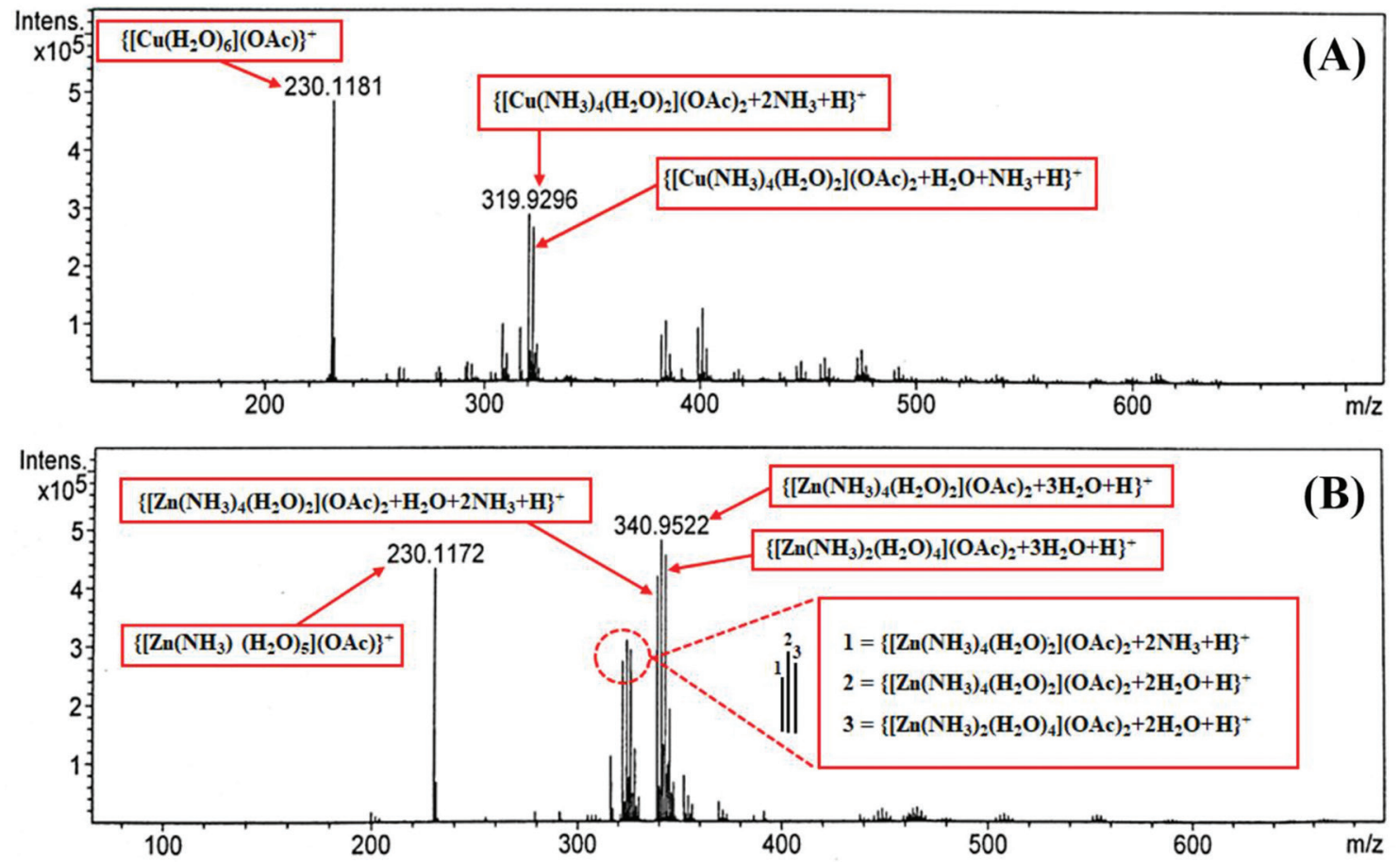

Figure 1: MALDI-TOF mass spectra of $(A) \mathrm{Cu}(\mathrm{Am})$ and $(\mathrm{B}) \mathrm{Zn}(\mathrm{Am})$ aqueous solutions, where $\mathrm{OAC}=\mathrm{CH}_{3} \mathrm{COO}^{-}$.

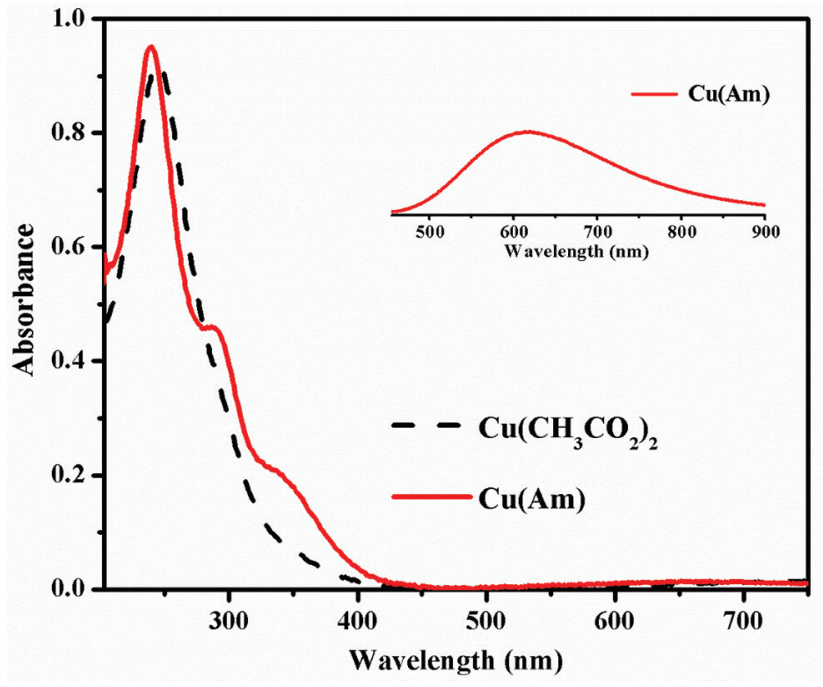

Figure 2: UV-vis spectra of $\mathrm{Cu}(\mathrm{Am})$ and $\mathrm{Cu}\left(\mathrm{CH}_{3} \mathrm{CO}_{2}\right)_{2}$.

peaks of $\mathrm{Cu}\left(\mathrm{NH}_{3}\right)_{4}^{2+}$, which were the predominant species, at $\approx 240$ and $605 \mathrm{~nm}$. The peak at $605 \mathrm{~nm}$ had much lower $\varepsilon$ as compared to that of $240 \mathrm{~nm}$.

\subsection{Catalytic activity of $\mathrm{Cu}(\mathrm{Am})$ and $\mathrm{Zn}(\mathrm{Am})$ in gelling and blowing reactions}

In the first step, the potential of $\mathrm{Cu}(\mathrm{Am})$ and $\mathrm{Zn}(\mathrm{Am})$ to catalyze urethane formation (gelling reaction) and $\mathrm{CO}_{2}$ generation (blowing reaction) was evaluated in RPUR foam system by comparing their experimental results to those of commercial DMCHA catalyst (Table 2). Tack-free time and expansion time relate to the ability of catalyst for completing gelling and blowing reactions, respectively. It was found that $\mathrm{RPUR} / \mathrm{Cu}(\mathrm{Am})-1: 1$ showed longer gelation time, but shorter tack-free time in comparison to RPUR/ DMCHA-1:1. This revealed that $\mathrm{Cu}(\mathrm{Am})$ could delay the reaction and viscosity buildup at initial stage, then it increased acceleration rate latter and completed the gelling reaction faster than DMCHA. This result indicates the good catalytic activity in gelling reaction of $\mathrm{Cu}(\mathrm{Am})$. $\mathrm{Zn}(\mathrm{Am})$ showed lower activity in gelling reaction than $\mathrm{Cu}(\mathrm{Am})$ and DMCHA. For blowing reaction times (start time and expansion time), $\mathrm{Cu}(\mathrm{Am})$ and $\mathrm{Zn}(\mathrm{Am})$ appeared less active in blowing reaction than DMCHA. However, the catalytic activity of $\mathrm{Cu}(\mathrm{Am})$ and $\mathrm{Zn}(\mathrm{Am})$ for blowing reaction was probably sufficient as the density of RPUR/ $\mathrm{Cu}(\mathrm{Am})-1: 1$ and $\mathrm{RPUR} / \mathrm{Zn}(\mathrm{Am})-1: 1$ was very close to that of RPUR/DMCHA-1:1. Catalytic characteristic of $\mathrm{Cu}(\mathrm{Am})$ and $\mathrm{Zn}(\mathrm{Am})$ was different from that of DMCHA. $\mathrm{Cu}(\mathrm{Am})$ and $\mathrm{Zn}(\mathrm{Am})$ gave slightly shorter tack-free time than expansion time, whereas DMCHA gave longer tack-free time than expansion time. This result revealed that the rate of polymer network formation obtained from $\mathrm{Cu}(\mathrm{Am})$ and $\mathrm{Zn}(\mathrm{Am})$ was slightly faster than the rate of foam rise. This could help to strengthen foam cells during the 
Table 2: Reaction times and density of RPUR and PIR-PUR foams.

\begin{tabular}{|c|c|c|c|c|c|}
\hline Catalysts & Start time (s) & Gelation time (s) & Tack-free time (s) & Expansion time (s) & Density $\left(\mathrm{kg} / \mathrm{m}^{3}\right)$ \\
\hline RPUR/DMCHA-1:1 & $21 \pm 1$ & $35 \pm 2$ & $196 \pm 3$ & $125 \pm 3$ & $34.7 \pm 0.7$ \\
\hline RPUR/Cu(Am)-1:1 & $26 \pm 1$ & $76 \pm 2$ & $176 \pm 6$ & $187 \pm 4$ & $38.1 \pm 0.7$ \\
\hline RPUR/Zn(Am)-1:1 & $25 \pm 1$ & $98 \pm 1$ & $202 \pm 2$ & $232 \pm 3$ & $33.4 \pm 0.9$ \\
\hline PIR-PUR/DMCHA+KOct-2:1 & $25 \pm 1$ & $46 \pm 1$ & $97 \pm 2$ & $141 \pm 2$ & $42.6 \pm 0.6$ \\
\hline PIR-PUR/DMCHA+KOct-2.5:1 & $28 \pm 1$ & $53 \pm 1$ & $122 \pm 2$ & $181 \pm 2$ & $51.6 \pm 0.7$ \\
\hline PIR-PUR/Cu(Am)+KOct-2:1 & $25 \pm 0$ & $36 \pm 1$ & $49 \pm 1$ & $70 \pm 1$ & $43.6 \pm 0.9$ \\
\hline PIR-PUR/Cu(Am)+KOct-2.5:1 & $28 \pm 1$ & $43 \pm 1$ & $70 \pm 2$ & $98 \pm 2$ & $52.7 \pm 1.3$ \\
\hline PIR-PUR/Zn(Am)+KOct-2:1 & $24 \pm 0$ & $37 \pm 1$ & $68 \pm 1$ & $97 \pm 2$ & $39.9 \pm 0.9$ \\
\hline PIR-PUR/Zn(Am)+KOct-2.5:1 & $27 \pm 0$ & $46 \pm 0$ & $92 \pm 1$ & $125 \pm 2$ & $50.4 \pm 0.8$ \\
\hline
\end{tabular}

foam rising process (31). Therefore, permanent structures without collapse and desirable dimensional stability (Figures S2-5) of RPUR/Cu(Am)-1:1 and RPUR/Zn(Am)-1:1 could be obtained.

\subsection{Preparation of PIR-PUR foams using $\mathrm{Cu}(\mathrm{Am})+\mathrm{KO} c t$ and $\mathrm{Zn}(\mathrm{Am})+\mathrm{KOct}$ as catalysts}

Reaction times of the foams are presented in Table 2. All PIR-PUR foams showed slight change in start time in comparison to that of RPUR foams. The small difference values of start time between both foams were less than $10 \mathrm{~s}$. For other reaction times, PIR-PUR foams accelerated using $\mathrm{Cu}(\mathrm{Am})+\mathrm{KOct}$ and $\mathrm{Zn}(\mathrm{Am})+$ KOct showed the reduction in gelation time, expansion time as well as tackfree time in comparison to those of their corresponding RPUR foams. For example, the gelation time, the tack-free time and the expansion time of PIR-PUR/Cu(Am)+KOct-2:1 decreased from RPUR/Cu(Am)-1:1 by $40 \mathrm{~s}, 127 \mathrm{~s}$ and $117 \mathrm{~s}$, respectively. The reduction in gelation time and tack-free time of PIR-PUR foams was resulted from the increase of isocyanurate crosslinks, which were more rigid than urethane crosslinks (32). This made PIR-PUR foams having viscosity buildup and reaching gel point faster than RPUR foams. The reduction in expansion time might be influenced by shorter tack-free time of PIR-PUR foams. In case of DMCHA+KOct, the gelation time of PIR-PUR foams catalyzed by DMCHA+KOct was slower than that of RPUR foams catalyzed by DMCHA alone. This suggested that DMCHA might lose partial reactivity in gelling reaction when using for PIR-PUR foam preparation. The similar incident can be found when using tertiary amine as the catalyst (33). Likewise, DMCHA partially dissolves in diethylene glycol (solvent of KOct) in the presence of water as a blowing agent (34). This can lead to inadequate miscibility between DMCHA and KOct solution and affects its reactivity. In contrast, metal-ammonia complex aqueous solutions and KOct solution in diethylene glycol were miscible due to the hydrogen bond association among water, ammonia and diethylene glycol. This leads to suitable homogeneous catalyst system of PIR-PUR foams, whose reaction mechanism catalyzed $\mathrm{Cu}(\mathrm{Am})+$ KOct and $\mathrm{Zn}(\mathrm{Am})+$ KOct is proposed in Scheme S1.

The increase of NCO:OH ratios slightly affected start time and gelation time, but prolonged tack-free time and expansion time. The reactions of PIR-PUR foams were gradually occurred after gel point due to the high crosslink density of polymer (30). Therefore, the duration for completing all reactions of PIR-PUR foams at higher NCO:OH ratios were extended. Foam density increased with higher $\mathrm{NCO}: \mathrm{OH}$ ratios owing to the increase of isocyanurate crosslink density (35). The fully waterblown PIR-PUR foams prepared from $\mathrm{Cu}(\mathrm{Am})+\mathrm{KOct}$ and $\mathrm{Zn}(\mathrm{Am})+\mathrm{KOct}$ had the density in the range of 39.9-52.7 $\mathrm{kg} / \mathrm{m}^{3}$, which was comparable to the density of PIR-PUR foams prepared using another commercial catalyst system and blowing with the mixture of water and hydrofluorocarbon (36).

\subsection{PIR yield and NCO conversion of PIR-PUR foams}

PIR yield and NCO conversion of reference RPUR and PIR-PUR foams were calculated (Figure 3). The peak area ratios of isocyanurate $\left(1415 \mathrm{~cm}^{-1}\right)$ to urethane $\left(1220 \mathrm{~cm}^{-1}\right)$ and the peak area reduction of isocyanate $\left(2277 \mathrm{~cm}^{-1}\right)$ of foams were used to calculate PIR/PUR ratios and NCO conversion, respectively. All data were normalized with the peak area of phenyl $\left(1595 \mathrm{~cm}^{-1}\right)$, which was constant and independent from all reactions. It was found that the PIR/PUR ratios of PIR-PUR foams were 
Table 3: TG/DTG data of RPUR and PIR-PUR foams.

\begin{tabular}{|c|c|c|c|c|c|c|c|c|c|c|}
\hline \multirow{2}{*}{ Samples } & \multirow{2}{*}{$\mathrm{T}_{5 \%}\left({ }^{\circ} \mathrm{C}\right)$} & \multicolumn{4}{|c|}{$1^{\text {st }}$ Stage } & \multicolumn{4}{|c|}{$2^{\text {nd }}$ Stage } & \multirow{2}{*}{$\begin{array}{r}\text { Char } \\
\text { residue } \\
\text { at } 800^{\circ} \mathrm{C} \\
(\%)\end{array}$} \\
\hline & & $\mathrm{T}_{\max 1}\left({ }^{\circ} \mathrm{C}\right)$ & $\begin{array}{r}\text { Weight } \\
\text { loss (\%) }\end{array}$ & $\begin{array}{r}\mathrm{Ea}(\mathrm{kJ} / \\
\mathrm{mol})\end{array}$ & $\mathbf{R}^{2}$ & $\mathrm{~T}_{\max 2}\left({ }^{\circ} \mathrm{C}\right)$ & $\begin{array}{r}\text { Weight } \\
\text { loss (\%) }\end{array}$ & $\begin{array}{r}\mathrm{Ea}(\mathrm{kJ} / \\
\mathrm{mol})\end{array}$ & $\mathbf{R}^{2}$ & \\
\hline RPUR/Cu(Am)-1:1 & 259 & 314 & 76.1 & 256.0 & 0.9995 & 466 & 11.9 & 306.1 & 0.9975 & 12.0 \\
\hline RPUR/Zn(Am)-1:1 & 238 & 307 & 76.0 & 254.3 & 0.9993 & 465 & 12.4 & 331.7 & 0.9995 & 11.6 \\
\hline PIR-PUR/Cu(Am)+KOct-2:1 & 266 & 314 & 61.6 & 357.7 & 0.9981 & 488 & 12.4 & 384.0 & 0.9975 & 26.0 \\
\hline PIR-PUR/Zn(Am)+KOct-2:1 & 260 & 311 & 64.4 & 350.9 & 0.9981 & 480 & 15.2 & 380.2 & 0.9982 & 20.4 \\
\hline
\end{tabular}

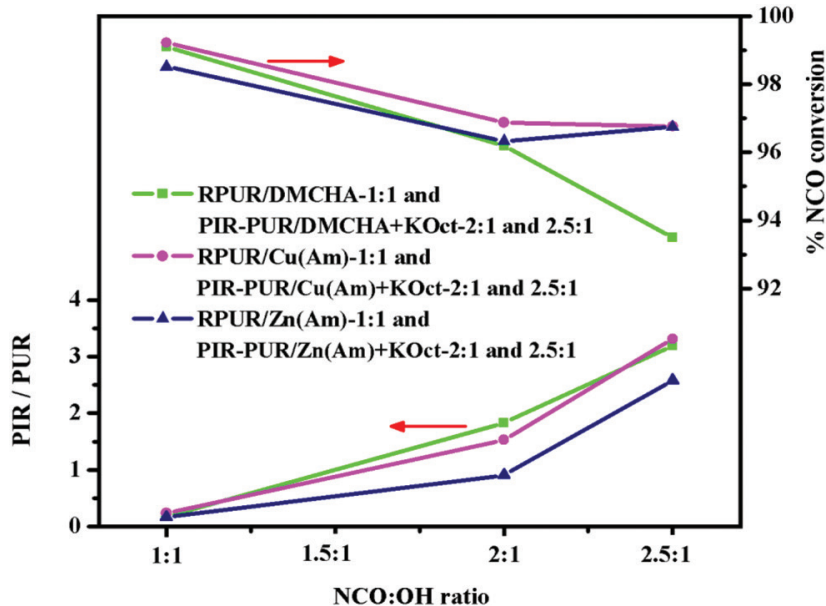

Figure 3: PIR/PUR ratios and \%NCO conversion of RPUR and PIR-PUR foams.

higher than those of RPUR foams for all catalyst types. At the same $\mathrm{NCO}: \mathrm{OH}$ ratio, $\mathrm{Zn}(\mathrm{Am})+\mathrm{KOct}$ gave lower PIR/PUR ratio in comparison to that of $\mathrm{Cu}(\mathrm{Am})+\mathrm{KOct}$ and DMCHA+KOct. Variation of $\mathrm{NCO}: \mathrm{OH}$ ratios also affected PIR yield (1,2,17,30). As expected, higher PIR/PUR ratios were obtained with increasing $\mathrm{NCO}: \mathrm{OH}$ ratios. However, the slight drop of NCO conversion was observed at higher $\mathrm{NCO}: \mathrm{OH}$ ratios. PIR-PUR foams obtained from $\mathrm{Cu}(\mathrm{Am})+\mathrm{KOct}, \mathrm{Zn}(\mathrm{Am})+\mathrm{KOct}$ and $\mathrm{DMCHA}+\mathrm{KOct}$ at the highest $\mathrm{NCO}: \mathrm{OH}$ ratio of 2.5:1 showed the $\mathrm{NCO}$ conversion of $96.8 \%, 96.8 \%$ and $93.5 \%$, respectively. Although this NCO conversion decreased from that of RPUR foams, it was still quantitative with more than $90 \%$ of the conversion. The slightly lower NCO conversion of PIR-PUR/DMCHA+KOct-2.5:1 did not affect its PIR yield, which still increased along with the increase of $\mathrm{NCO}: \mathrm{OH}$ ratios.

\subsection{Morphology of PIR-PUR foams}

Figure 4 compares the cell morphology between RPUR/Cu(Am)-1:1 (Figures 4a and 4b) and PIR-PUR/
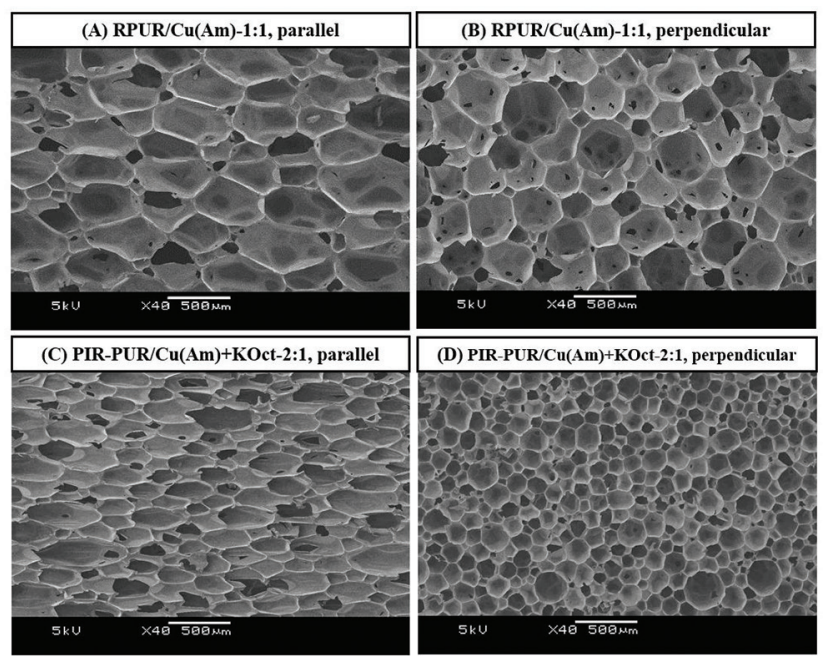

Figure 4: SEM images of RPUR and PIR-PUR foams.

$\mathrm{Cu}(\mathrm{Am})+\mathrm{KOct}-2: 1$ (Figures $4 \mathrm{c}$ and $4 \mathrm{~d}$ ) in different foam rise directions. The cell morphology of the foams catalyzed by $\mathrm{Zn}(\mathrm{Am})$, DMCHA, $\mathrm{Zn}(\mathrm{Am})+\mathrm{KOct}$ and DMCHA+KOct is shown in Figure S6. It was found that all PIR-PUR foams showed well-defined closed cells regardless of catalyst types. The cell morphology showed anisotropic structures appearing elongated and spherical structures in parallel and perpendicular directions, respectively, to foam rise. Figure 5 presents the average cell diameter of RPUR and PIR-PUR foams in perpendicular direction to foam rise. In comparison to RPUR foams, PIR-PUR foams showed the large decrease in average cell size until the NCO:OH ratio reached to 2:1. The smaller average cell size of PIR-PUR foams could be attributed to the faster gelation time and the increase of isocyanurate crosslink density, which decreased the cell wall elasticity for bubble expansion and suppressed the growth of foam cell during foam rise $(31,37,38)$. The slight increase of average cell size at NCO:OH ratio of 2.5:1 related with the viscosity reduction of starting materials and the retarded polymerization rate when increasing PMDI content in foam recipe. This result revealed the complex relation between crosslink density, 


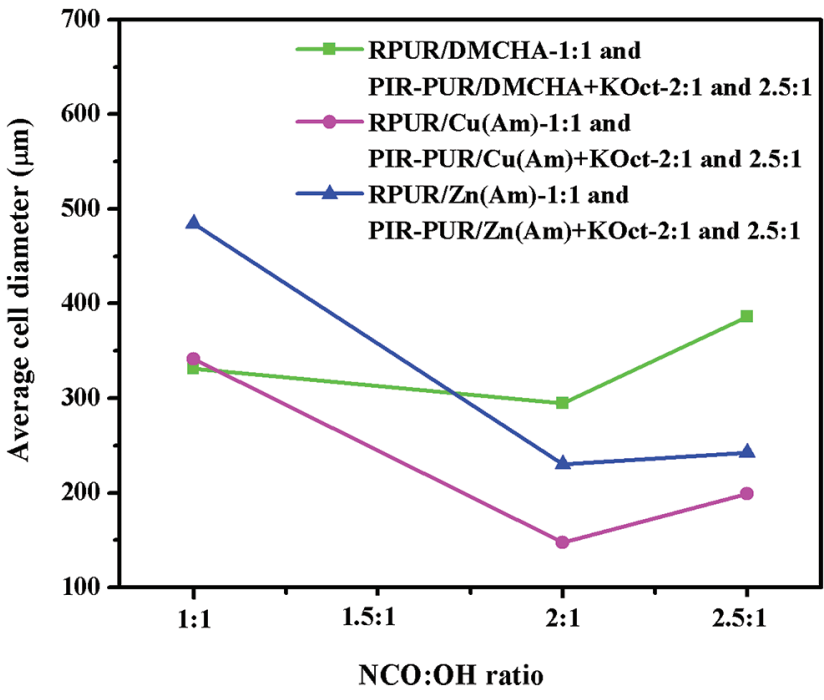

Figure 5: Average cell diameter of RPUR and PIR-PUR foams in perpendicular direction to foam rise.

viscosity and polymerization rate, which competed to each other to control the final cell size of the foams.

\subsection{Mechanical properties of PIR-PUR foams}

PIR-PUR/Cu(Am)+KOct-2:1, PIR-PUR/Zn(Am)+KOct-2:1 and PIR-PUR/DMCHA+KOct-2:1 were investigated compressive properties because they had suitable apparent density in the range of industrial foams $\left(30-50 \mathrm{~kg} / \mathrm{m}^{3}\right)$ (39). Figures $6 \mathrm{a}$ and $6 \mathrm{~b}$ present compressive curves of reference RPUR and PIR-PUR foams in different foam rise directions. Figures $6 \mathrm{c}$ and $6 \mathrm{~d}$ present their compressive strength as the function of foam density and catalysts. All PIR-PUR and RPUR foams exhibited anisotropic behavior. Their compressive strength in parallel direction showed superior in comparison to that in perpendicular direction, which originated from the different cell morphology in different foam rise direction $(40,41)$. PIR-PUR foams showed higher compressive strength than RPUR foams due to the stronger isocyanurate crosslink that could lead polymer matrix to withstand better with compressive stress (30). The compressive strength of all RPUR foams, PIR-PUR/ $\mathrm{Cu}(\mathrm{Am})+\mathrm{KOct}-2: 1$ and PIR-PUR/Zn(Am)+KOct-2:1 increased with increasing their foam density in both foam rise directions. For example, The apparent density of PIR-PUR/ $\mathrm{Cu}(\mathrm{Am})+\mathrm{KOct}-2: 1$ and PIR-PUR/Zn(Am)+KOct-2:1 were 43.6 and $39.9 \mathrm{~kg} / \mathrm{m}^{3}$, respectively. Therefore, the compressive strength in parallel and perpendicular directions of PIR-PUR/Cu(Am)+KOct-2:1 was 239.9 and $151.4 \mathrm{kPa}$, respectively, which was higher than that of PIR-PUR/ $\mathrm{Zn}(\mathrm{Am})+$ KOct-2:1 (218.5 and $141.8 \mathrm{kPa}$, respectively).
However, PIR-PUR/DMCHA+KOct-2:1 showed the different results. PIR-PUR/DMCHA+KOct-2:1, which had middle foam density between PIR-PUR/Cu(Am)+KOct-2:1 and PIR-PUR/Zn(Am)+KOct-2:1, showed the lowest compressive strength in parallel direction in comparison to PIR-PUR/ $\mathrm{Cu}(\mathrm{Am})+\mathrm{KOct}-2: 1$ and PIR-PUR/Zn(Am)+KOct-2:1. Foam rupture in parallel direction of PIR-PUR/DMCHA+KOct-2:1 was observed during compression test resulting in the brittle feature of its stress-strain curve (Figure 6a) and the lowest compressive strength (Figure 6c). Both PIR-PUR/ $\mathrm{Cu}(\mathrm{Am})+$ KOct-2:1 and PIR-PUR/Zn(Am)+KOct-2:1 appeared to be tough materials since the foam rupture was not observed during compression test.

\subsection{Flame retardant properties of PIR-PUR foams}

Experimental data from horizontal burning test and \% LOI (Figure 7) indicates the flame retardancy of the foams. Digital images of burnt foams after horizontal burning test as the function of catalysts and $\mathrm{NCO}: \mathrm{OH}$ ratios are presented in Figure S7. All RPUR foams, especially RPUR/ Zn(Am)-1:1, were easily ignited and drastically burnt owing to their highly flammable feature of cellular polymers $(4,42)$. Flame blaze rapidly propagated and totally covered $150 \mathrm{~mm}$ of the specimen length. Many small holes and crack surface were observed throughout of burnt foam. Among RPUR foams, RPUR/Zn(Am)-1:1 had the poorest flame retardancy due to the lowest foam density and PIR/PUR ratio. Generally, the flame retardancy of cellular polymers probably depends on the foam density. The foams with lower density can be readily ignited and have poorer fire resistance (42). This result pointed out that the gelling/blowing catalysts, namely DMCHA, $\mathrm{Cu}(\mathrm{Am})$ and $\mathrm{Zn}(\mathrm{Am})$, also affected flame retardancy of the foams through the density adjustment, which depended on the catalytic activity of each catalyst.

PIR-PUR foams distinctly showed better flame retardancy. Shorter ignition length and self-extinguishing were observed. Ignition length (Figure 7a), afterglow time (Figure $7 \mathrm{~b}$ ) and burning rate (Figure 7c) of all PIR-PUR foams prepared at the $\mathrm{NCO}: \mathrm{OH}$ ratio of 2:1 decreased from those of their corresponding RPUR foams. For instance, RPUR/Cu(Am)-1:1 showed $150.0 \mathrm{~mm}$ of ignition length, $63.0 \mathrm{~s}$ of afterglow time and $145.2 \mathrm{~mm} / \mathrm{min}$ of burning rate, while PIR-PUR/Cu(Am)+KOct-2:1 showed $38.4 \mathrm{~mm}$ of ignition length, $19.0 \mathrm{~s}$ of afterglow time and $42.1 \mathrm{~mm} / \mathrm{min}$ of burning rate. The ignition length of PIR-PUR foams prepared at the $\mathrm{NCO}: \mathrm{OH}$ ratio of 2.5:1 was approximately sevenfold decrease from that of related RPUR foams. 

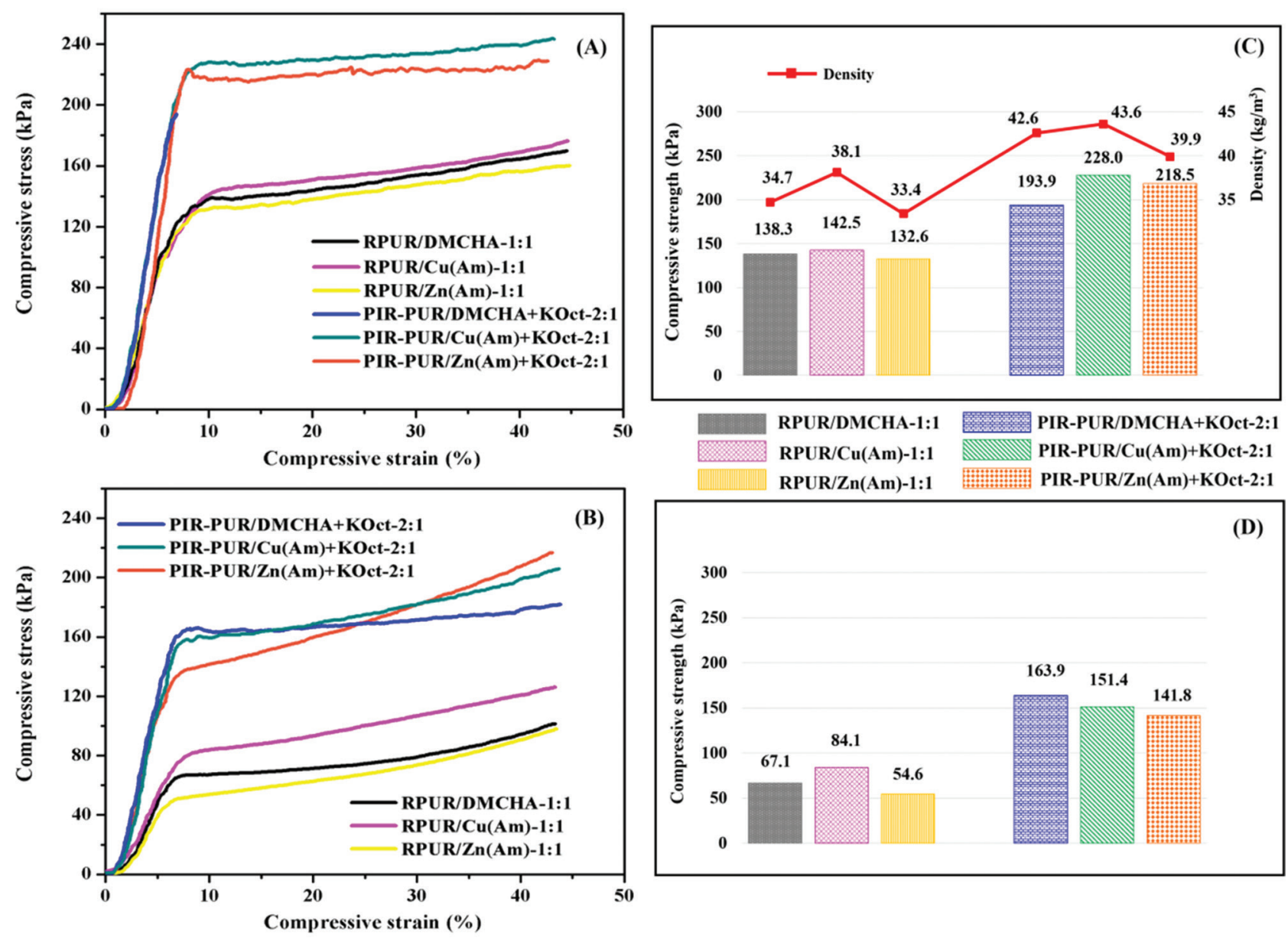

Figure 6: Compressive properties of RPUR and PIR-PUR foams; $(a, b)$ are stress-strain curves in parallel and perpendicular directions, respectively, to foam rise, $(c, d)$ are compressive strength in parallel and perpendicular directions, respectively, to foam rise.

Afterglow time and burning rate could not be obtained as these foams almost instantaneously extinguished after removing ignition source. According to the material classification of ASTM D4986-03, all RPUR foams cannot be classified to any rating of fire-resistant materials due to their low flame retardancy. All PIR-PUR foams prepared at the NCO:OH ratios of 2:1 and 2.5:1 can be classified to HF1 rating (the highest classification) defined as the cellular materials having afterglow time $\leq 30$ s and ignition length $<60 \mathrm{~mm}$.

Figure $7 \mathrm{~d}$ shows \%LOI of the foams. It was found that \%LOI of PIR-PUR foams were higher than those of their corresponding RPUR foam. Reference RPUR foams had low \%LOI of 18.3-18.5\%, which indicated that all RPUR foams were ready to burn in air when exposed to fire. \%LOI of PIR-PUR foams prepared at the $\mathrm{NCO}: \mathrm{OH}$ ratios of 2:1 and 2.5:1 were in the range 20.6-20.9 and 21.2-21.5\%, respectively. The increase of \%LOI is in agreement with the results of horizontal burning test. The improvement in flame retardancy of the foams correlates with the enlargement of PIR crosslinks, which are inherent fire-resistant structures, accompanying with more char content generated during the combustion of PIR-PUR foams (16).

Therefore, SEM images of the char layer on burnt foam surface were observed (Figure 8). The char amount and the burnt surface morphology between RPUR and PIR-PUR foams were quite different. All RPUR foams had small char formation (Figures 8a-c). Many microholes were observed on their surface and incessantly permitted heat and oxygen transferring to participate in the combustion cycle of internal polymer resulting in destroyed cellular structures (43). On the contrary, dense char layers deposited on the burnt surface of PIR-PUR/DMCHA+KOct-2:1, PIR-PUR/ $\mathrm{Cu}(\mathrm{Am})+\mathrm{KOct}-2: 1$ and PIR-PUR/Zn(Am)+KOct-2:1 were observed (Figures 8d-f). These dense char layers produced by PIR structures, which facilitated to form carbonaceous char during thermal-oxidative degradation $(4,32)$, could enhance flame retardant behaviors of the foams by suppressing the volatile fuel produced from 


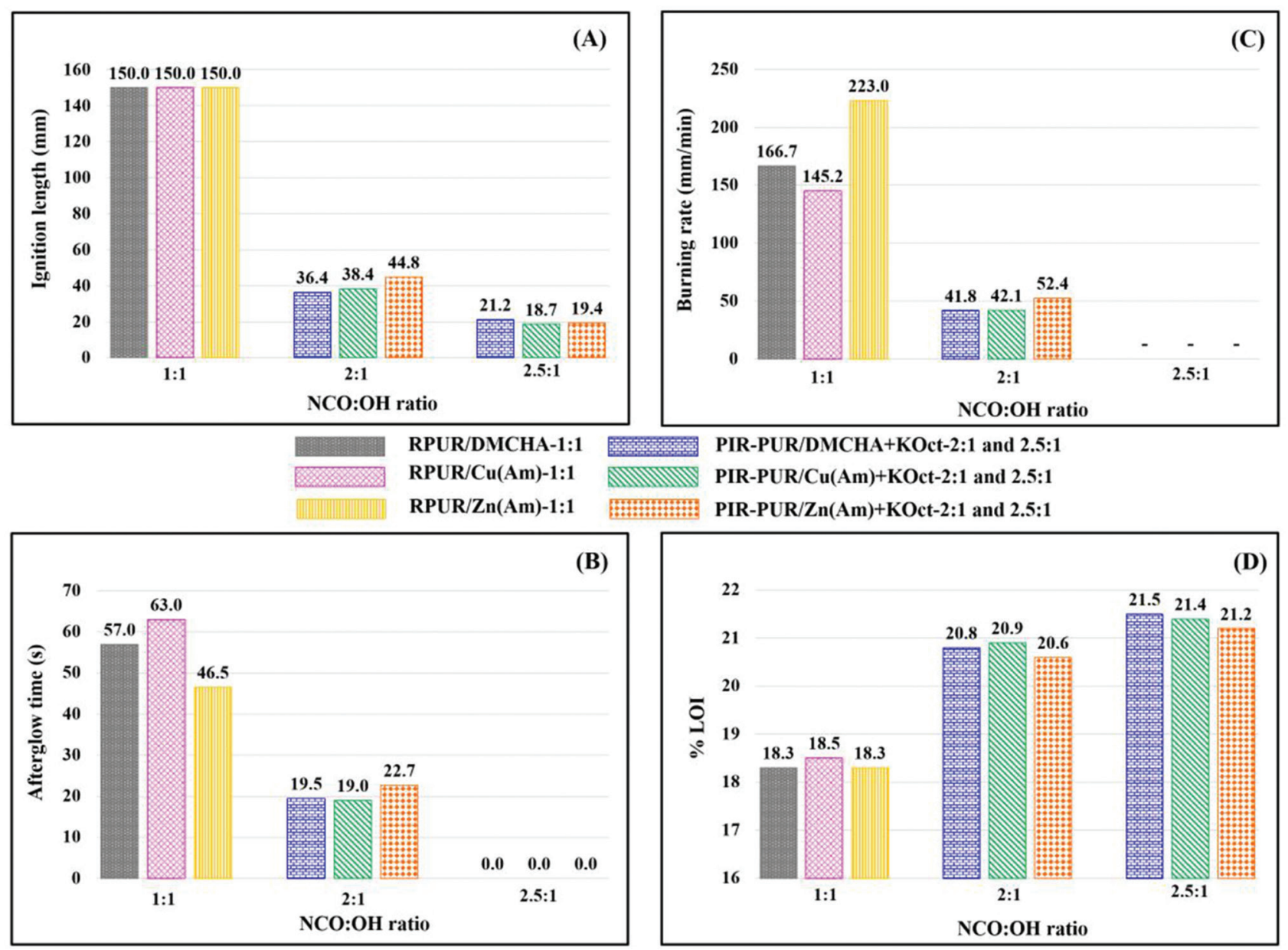

Figure 7: Results of horizontal burning test and \% limiting oxygen index.

polymer degradation, providing the insulating layers for decreasing heat and mass transfer between combustion phases and acting as the barriers to protect further diffusion of oxygen into underlying combustible polymer $(4,16,32)$.

\subsection{Thermostability of PIR-PUR foams}

Thermostability of PIR-PUR/Cu(Am)+KOct-2:1 and PIR-PUR/Zn(Am)+KOct-2:1 was further investigated because of their proper mechanical properties without the brittleness as discussed in the previous section. Figure 9 presents TG/DTG thermograms of the foams. All foams had two thermal degradation stages. The first stage showed the weight loss between 250 to $400^{\circ} \mathrm{C}$, which is attributed to thermal decomposition of urethane bonds as well as polyol segments. The second degradation stage took place between 450 to $600^{\circ} \mathrm{C}$, which is corresponded to the degradation of isocyanurate and aromatic compounds
$(16,32)$. Experimental data from TG/DTG thermograms are tabulated in Table 3.

Initial degradation temperature $\left(\mathrm{T}_{5 \%}\right)$ can be designated as an index indicating the thermal stability of materials (44). RPUR/Cu(Am)-1:1 and RPUR/Zn(Am)-1:1 showed $\mathrm{T}_{5 \%}$ at 259 and $238^{\circ} \mathrm{C}$, respectively, while PIR-PUR/ $\mathrm{Cu}(\mathrm{Am})+$ KOct-2:1 and PIR-PUR/Zn(Am)+KOct-2:1 showed higher $\mathrm{T}_{5 \%}$ at 266 and $260^{\circ} \mathrm{C}$, respectively. The presence of isocyanurate linkage can increase overall crosslink density of PIR-PUR foam. This leads PIR-PUR foams to require more thermal energy for initiating polymer chain movements at the onset of degradation process. $\mathrm{T}_{\max 1}$ and $\mathrm{T}_{\max 2}$ are temperature at the highest weight loss rate of each degradation stage. There were barely significant differences of $\mathrm{T}_{\max 1}$ between RPUR and PIR-PUR foams. However, $\mathrm{T}_{\max 2}$ of PIR-PUR/Cu(Am)+KOct-2:1 and PIR-PUR/Zn(Am)+KOct-2:1 shifted to higher temperature at 488 and $480^{\circ} \mathrm{C}$, respectively, in comparison to those of RPUR/Cu(Am)-1:1 and RPUR/Zn(Am)-1:1 at 466 and $465^{\circ} \mathrm{C}$, respectively. 


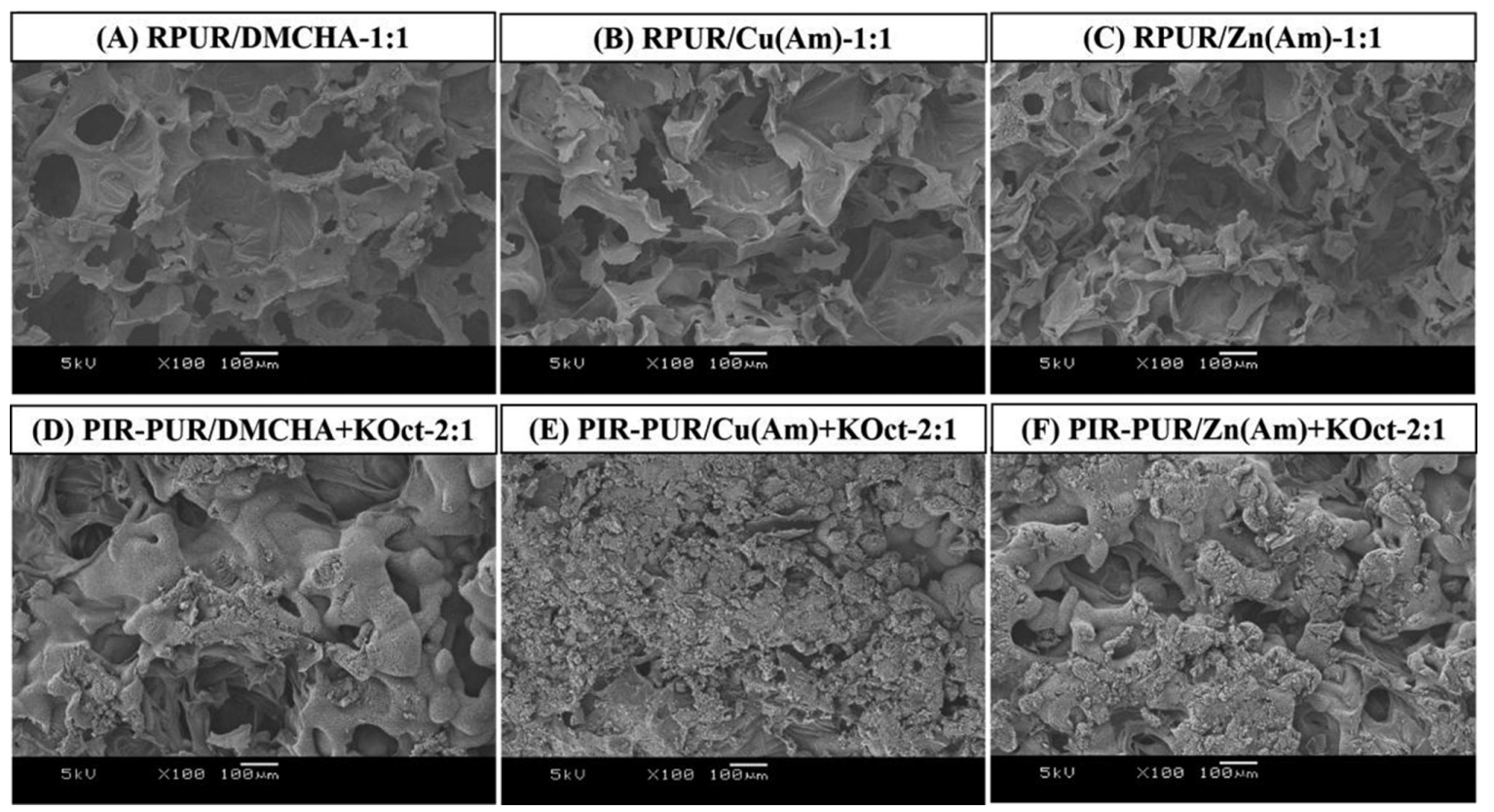

Figure 8: SEM images of char residue on burnt surface of RPUR and PIR-PUR foams after horizontal burning test.

Determination of char residue by TGA is the relative method for evaluating the flame retardancy of polymer (4). The char residue at $800^{\circ} \mathrm{C}$ of PIR-PUR/Cu(Am)+KOct-2:1 and PIR-PUR/Zn(Am)+KOct-2:1 increased to 26.0 and $20.4 \%$, respectively, in comparison to their reference RPUR foams. It can be deduced that isocyanurate can act as a charring agent to endow the char formation, which is advantageous to enhance not only the thermal stability but also the flame retardancy of PIR-PUR foams.

Activation energy $\left(E_{a}\right)$ of each thermal degradation stage was calculated according to Horowitz-Metzger method using Eq. 1 (45):

$$
\ln \left[\ln \left(\mathrm{W}_{0}-\mathrm{W}_{\mathrm{t}}^{\mathrm{f}}\right) /\left(\mathrm{W}-\mathrm{W}_{\mathrm{t}}^{\mathrm{f}}\right)\right]=\mathrm{E}_{\mathrm{a}} \theta / \mathrm{RT}_{\mathrm{s}}^{2}
$$

Where $\mathrm{W}_{0}$ and $\mathrm{W}_{\mathrm{t}}^{\mathrm{f}}$ are the weight before and after each thermal degradation. $\mathrm{W}$ is the weight at reference temperature (T). $\theta$ is the difference of $T$ and $T_{s}$, when $T_{s}$ is $\mathrm{T}_{\max 1}$ or $\mathrm{T}_{\max 2^{*}}$. The plots of $\ln \left[\ln \left(\mathrm{W}_{0}-\mathrm{W}_{\mathrm{t}}^{\mathrm{f}}\right) /\left(\mathrm{W}-\mathrm{W}_{\mathrm{t}}^{\mathrm{f}}\right)\right]$ versus $\theta$ (Figure S8) provide straight lines, whose slope can be used to calculate $\mathrm{E}_{\mathrm{a}}$ of each thermal degradation stage (Table 3). The slope data for $\mathrm{E}_{\mathrm{a}}$ calculation could be obtained with suitable correlation coefficients $\left(R^{2}\right)>0.99$. It was observed that $\mathrm{E}_{\mathrm{a}}$ values of the second degradation stage (isocyanurate degradation) were higher than those of the first degradation stage (urethane degradation) for all foam samples. Isocyanurate structures are thermally stable than urethane structures and therefore need more energies for bond scission $(2,4,32)$. PIR-PUR/Cu(Am)+KOct-2:1 and PIR-PUR/Zn(Am)+KOct-2:1 had higher $\mathrm{E}_{\mathrm{a}}$ than RPUR/
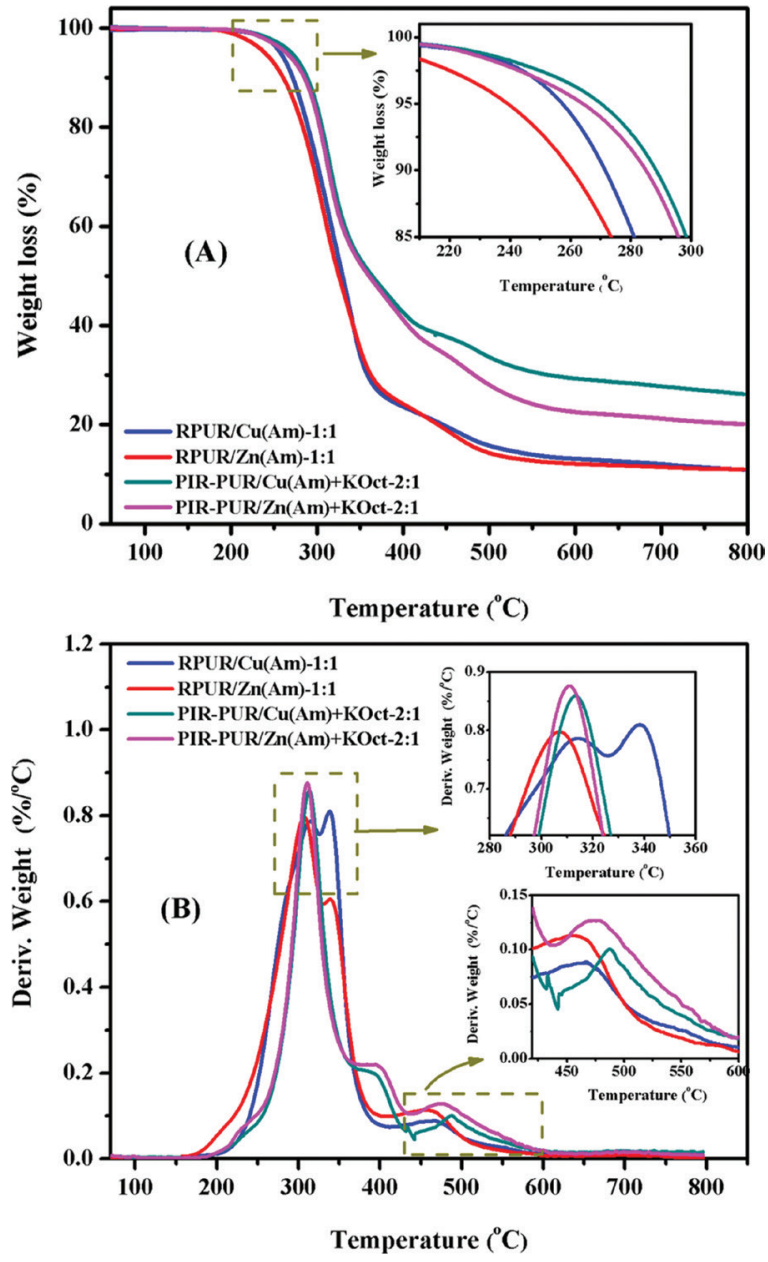

Figure 9: (a) TG and (b) DTG thermograms of RPUR and PIR-PUR foams. 
$\mathrm{Cu}(\mathrm{Am})-1: 1$ and RPUR/Zn(Am)-1:1, respectively, for both degradation stages. This result indicates the higher thermal stability of the modified PIR-PUR foams.

\section{Conclusions}

Two systems of homogeneous catalyst in aqueous solution, $\mathrm{Cu}(\mathrm{Am})+\mathrm{KOct}$ and $\mathrm{Zn}(\mathrm{Am})+\mathrm{KOct}$, were used to prepare PIR-PUR foams and the results were compared to that prepared from DMCHA+KOct. The in situ complex formation of metal acetate with ammonia could occur in water to give $\mathrm{Cu}(\mathrm{Am})$ and $\mathrm{Zn}(\mathrm{Am})$. At the optimum molar ratio of metal acetate:ammonia $=1: 6$, major species in the aqueous solutions of $\mathrm{Cu}(\mathrm{Am})$ and $\mathrm{Zn}(\mathrm{Am})$ were $\left[\mathrm{Cu}\left(\mathrm{NH}_{3}\right)_{4}\left(\mathrm{H}_{2} \mathrm{O}\right)_{2}\right](\mathrm{OAc})_{2}$ and $\left[\mathrm{Zn}\left(\mathrm{NH}_{3}\right)_{4}\left(\mathrm{H}_{2} \mathrm{O}\right)_{2}\right](\mathrm{OAc})_{2}$, respectively. Both $\mathrm{Cu}(\mathrm{Am})$ and $\mathrm{Zn}(\mathrm{Am})$ showed their ability to catalyze both blowing and gelling reactions of RPUR foams. $\mathrm{Cu}(\mathrm{Am})$ showed higher catalytic activity than $\mathrm{Zn}(\mathrm{Am})$. PIR-PUR foams prepared from $\mathrm{Cu}(\mathrm{Am})+\mathrm{KOct}$ and DMCHA+KOct had close PIR yields and flame retardancy, while those prepared from $\mathrm{Zn}(\mathrm{Am})+\mathrm{KOct}$ had slightly lower flame retardancy due to less PIR yield and foam density. During compression test, PIR-PUR foam prepared from DMCHA+KOct was brittle and foam rupture was observed, while those prepared from $\mathrm{Cu}(\mathrm{Am})+\mathrm{KOct}$ and $\mathrm{Zn}(\mathrm{Am})+$ KOct did not show foam rupture. TGA results showed that initial degradation temperature, activation energy for thermal degradation and char residue of PIR-PUR foams were higher than those of RPUR foams, which indicated the enhancement in thermal stability of PIR-PUR foams.

Acknowledgements: IRPC Public Company Ltd. is gratefully acknowledged for the chemical supplying used in the foam preparation. BS thanks Chulalongkorn University for her Ph.D. Scholarship (grant \# GCUGE15).

\section{References}

1. Randall D., Lee S. (Eds.), Huntsman polyurethanes - the polyurethanes book. John Wiley \& Sons, United Kingdom, 2002.

2. Ashida K., Polyurethane and related foams: chemistry and technology. CRC Press, New York, 2006.

3. Szycher M., Szycher's handbook of polyurethanes (2nd ed.). CRC Press, Florida, USA, 2012.

4. Chattopadhyay D., Webster D.C., Thermal stability and flame retardancy of polyurethanes. Prog Polym Sci, 2009, 34(10), 1068-1133.

5. Cear S., Feltzin J., Baldino J.P., Polyisocyanurate foams having low friability and flame spread. J Cell Plast, 1977, 13(1), 21-25.
6. Chen K., Tian C., Liang S., Zhao X., Wang X., Effect of stoichiometry on the thermal stability and flame retardation of polyisocyanurate foams modified with epoxy resin. Polym Degrad Stab, 2018, 150, 105-113.

7. Saiki K., Sasaki K., Ashida K., Carbodiimide-modified polyisocyanurate foams: preparation and flame resistance. J Cell Plast, 1994, 30(5), 470-484.

8. Dominguez-Rosado E., Liggat J.J., Snape C.E., Eling B., Pichtel J., Thermal degradation of urethane modified polyisocyanurate foams based on aliphatic and aromatic polyester polyol. Polym Degrad Stab, 2002, 78(1), 1-5.

9. Liszkowska J., Czupryński B., Paciorek-Sadowska J., Tris (hydroxydietylene)-2-hydroxypropane-1, 2, 3-tricarboxylate for rigid PUR-PIR foams. J Polym Eng, 2015, 35(8), 743-751.

10. Liszkowska J., Czupryński B., Paciorek-Sadowska J., Thermal properties of polyurethane-polyisocyanurate (PUR-PIR) foams modified with tris (5-hydroxypenthyl) citrate. J Adv Chem Eng, 2016, 6(2), 1000148.

11. Liszkowska J., The use of citric acid in the production of polyols for rigid PUR-PIR foams. Polym Bull, 2017, 74(1), 283-305.

12. Liszkowska J., Czupryński B., Paciorek-Sadowska J., The effect of hydroxyalkyls, derivatives of 2-hydroxypropane-1.2.3-tricarboxylic acid, on flammability and thermal properties of PUR-PIR foams. Polym Bull, 2018, 75(8), 3801-3823.

13. Okuzono S., Tokumoto K., Tamano Y., Lowe D.W., New polyisocyanurate catalysts which exhibit high activity at low temperature. J Cell Plast, 2001, 37(1), 72-89.

14. Naruse A., Nanno H., Kurita M., Inohara H., Fukami T., Development of all water-blown polyisocyanurate foam system for metal-faced continuous sandwich panels. J Cell Plast, 2002, 38(5), 385-401.

15. Romero R.R., Grigsby R.A., Rister E.L., Pratt J.K., Ridgway D., A study of the reaction kinetics of polyisocyanurate foam formulations using real-time FTIR. J Cell Plast, 2005, 41(4), 339-359.

16. Gao L., Zheng G., Zhou Y., Hu L., Feng G., Zhang M., Synergistic effect of expandable graphite, diethyl ethylphosphonate and organically-modified layered double hydroxide on flame retardancy and fire behavior of polyisocyanurate-polyurethane foam nanocomposite. Polym Degrad Stab, 2014, 101, 92-101.

17. Lövenich C.J., Raffel B., A quantitative investigation of the effect of the recipe on the trimer-yield in polyisocyanurate foams. J Cell Plast, 2006, 42(4), 289-305.

18. Modesti M., Lorenzetti A., Flame retardancy of polyisocyanurate-polyurethane foams: use of different charring agents. Polym Degrad Stab, 2002, 78(2), 341-347.

19. Hathaway B.J., Tomlinson A.A.G., Copper(II) ammonia complexes. Coord Chem Rev, 1970, 5(1), 1-43.

20. Bjerrum J., On the tendency of the metal ions toward complex formation. Chem Rev, 1950, 46(2), 381-401.

21. Kauffman G.B., Eduard Schweizer (1818-1860): the unknown chemist and his well-known reagent. J Chem Educ, 1984, 61(12), 1095-1097.

22. Vazquez-Arenas J., Lazaro I., Cruz R., Electrochemical study of binary and ternary copper complexes in ammonia-chloride medium. Electrochim Acta, 2007, 52(20), 6106-6117.

23. Giannopoulou I., Panias D., Paspaliaris I., Electrochemical modeling and study of copper deposition from concentrated ammoniacal sulfate solutions. Hydrometallurgy, 2009, 99, 58-66. 
24. Pavelka M., Burda J.V., Theoretical description of copper Cu (I)/Cu (II) complexes in mixed ammine-aqua environment. DFT and ab initio quantum chemical study. Chem Phys, 2005, 312, 193-204.

25. Hu J., Chen Q., Hu H., Chen X., Hu F., Yin Z., XAS investigation on the coordination structure and extraction mechanism of zinc (II) in ammoniacal solution. Sep Purif Technol, 2012, 98, 308-314.

26. Chen J., Wu X., Gong Y., Wang P., Li W., Mo S., et al., General synthesis of transition-metal oxide hollow nanospheres/ nitrogen-doped graphene hybrids by metal-ammine complex chemistry for high-performance lithium-ion batteries. Chem Eur J, 2018, 24(9), 2126-2136.

27. Armbruster T., Simoncic P., Döbelin N., Malsy A., Yang P., $\mathrm{Cu}^{2+}$-acetate and $\mathrm{Cu}^{2+}$-ammine exchanged heulandite: a structural comparison. Micropor Mesopor Mater, 2003, 57(2), 121-131.

28. Yashnik S., Ismagilov Z., Cu-substituted ZSM-5 catalyst: controlling of DeNOx reactivity via ion-exchange mode with copper-ammonia solution. Appl Catal B, 2015, 170, 241-254.

29. Sridaeng D., Jitaree W., Thiampanya P., Chantarasiri N., Preparation of rigid polyurethane foams using low-emission catalysts derived from metal acetates and ethanolamine. e-Polymers, 2016, 16(4), 265-275.

30. Modesti M., Lorenzetti A., An experimental method for evaluating isocyanate conversion and trimer formation in polyisocyanatepolyurethane foams. Eur Polym J, 2001, 37(5), 949-954.

31. Mondal P., Khakhar D., Hydraulic resistance of rigid polyurethane foams. III. Effect of variation of the concentration of catalysts on foam structure and properties. J Appl Polym Sci, 2004, 93(6), 2838-2843.

32. Xu Q., Hong T., Zhou Z., Gao J., Xue L., The effect of the trimerization catalyst on the thermal stability and the fire performance of the polyisocyanurate-polyurethane foam. Fire Mater, 2018, 42(1), 119-127.

33. Carleton P.S., Lockwood R.J., Reymore H.E.J., Polyisocyanatebased foam process using aminimides as catalyst. U.S. patent, 1975, 3, 925, 284.

34. Góral M., Shaw D.G., Mączyński A., Wiśniewska-Gocłowska B., Oracz P., IUPAC-NIST solubility data series. 96. amines with water part 2. $\mathrm{C}_{7}-\mathrm{C}_{24}$ aliphatic amines. J Phys Chem Ref Data, 2012, 41(4), 043107.

35. Nacas A.M., Ito N.M., Sousa R.R.D., Spinacé M.A., Dos Santos D.J., Effects of $\mathrm{NCO}: \mathrm{OH}$ ratio on the mechanical properties and chemical structure of Kraft lignin-based polyurethane adhesive. J Adhes, 2017, 93, 18-29.

36. Zatorski W., Brzozowski Z.K., Kolbrecki A., New developments in chemical modification of fire-safe rigid polyurethane foams. Polym Degrad Stab, 2008, 93(11), 2071-2076.

37. Dusek K., Spirkova M., Havlicek I., Network formation of polyurethanes due to side reactions. Macromolecules, 1990, 23(6), 1774-1781.

38. Paruzel A., Michałowski S., Hodan J., Horák P., Prociak A., Beneš H., Rigid polyurethane foam fabrication using medium chain glycerides of coconut oil and plastics from end-of-life vehicles. ACS Sustain Chem Eng, 2017, 5(7), 6237-6246.

39. Bhoyate S., Ionescu M., Kahol P.K., Gupta R.K., Sustainable flame-retardant polyurethanes using renewable resources. Ind Crops Prod, 2018, 123, 480-488.

40. Kurańska M., Prociak A., Kirpluks M., Cabulis U., Polyurethanepolyisocyanurate foams modified with hydroxyl derivatives of rapeseed oil. Ind Crops Prod, 2015, 74, 849-857.

41. Hejna A., Kosmela P., Kirpluks M., Cabulis U., Klein M., Haponiuk J., et al., Structure, mechanical, thermal and fire behavior assessments of environmentally friendly crude glycerol-based rigid polyisocyanurate foams. J Polym Environ, 2018, 26(5), 1854-1868.

42. Shi L., Li Z.M., Xie B.H., Wang J.H., Tian C.R., Yang M.B., Flame retardancy of different-sized expandable graphite particles for high-density rigid polyurethane foams. Polym Int, 2006, 55(8), 862-871.

43. Wang X., Pan Y.T., Wan J.T., Wang D.Y., An eco-friendly way to fire retardant flexible polyurethane foam: layer-by-layer assembly of fully bio-based substances. RSC Adv, 2014, 4(86), 46164-46169.

44. Zhang P., Tian S., Fan H., Chen Y., Yan J., Flame retardancy and hydrolysis resistance of waterborne polyurethane bearing organophosphate moieties lateral chain. Prog Org Coat, 2015, 89, 170-180.

45. Horowitz H.H., Metzger G., A new analysis of thermogravimetric traces. Anal Chem, 1963, 35(10), 1464-1468. 